\title{
PENGARUH MODEL PROBLEM BASED LEARNING (PBL) BERBASIS CHILDREN LEARNING IN SCIENCE (CLIS) TERHADAP MOTIVASI BELAJAR PESERTA DIDIK
}

\author{
Muh. Syihab Ikbal \\ Universitas Islam Negeri Alauddin Makassar \\ e-mail : syihab.ikbal@uin-alauddin.ac.id
}

\begin{abstract}
The Influence of Problem Based Learning (PBL) Model Based on Children Learning in Science (CLIS) on Students' Learning Motivation. This research is a quasi-experimental research which aims to determine the description of the learning motivation of students who are taught with CLIS-based PBL learning models and conventional models and to find out the effect on students' learning motivation. The research design used was the matching only post test group design. The study population numbered 136 people spread over 4 classes. The research sample consisted of 36 people spread over 2 classes. The results showed that the average score of students' learning motivation who was taught by the CLIS-based PBL learning model was greater than the conventional model, that is 77,97 $>66,75$. The results of hypothesis testing show the value of $t_{\text {count }}>t_{\text {table }}$ (9.081>1,997), so it is concluded that the CLIS-based PBL learning model has a better effect than the conventional model on the learning motivation of students.
\end{abstract}

Keywords: problem based learning, CLIS, motivation

\begin{abstract}
Abstrak: Pengaruh Model Problem Based Learning (PBL) Berbasis Children Learning in Science (CLIS) Terhadap Motivasi Belajar Peserta Didik. Penelitian ini merupakakn penelitian kuasi eksperimen yang bertujuan untuk mengetahui gambaran motivasi belajar peserta didik yang diajar dengan model pembelajaran PBL berbasis CLIS dan model konvensional serta mengetahui pengaruhnya terhadap motivasi belajar peserta didik. Desain penelitian yang digunakan adalah the matching only post test group design. Populasi penelitian berjumlah 136 orang yang tersebar pada 4 kelas. Sampel penelitian berjumlah 36 orang yang tersebar pada 2 kelas. Hasil penelitian menunjukkan bahwa rata-rata skor motivasi belajar peserta didik yang diajar dengan model pembelajaran PBL berbasis CLIS lebih besar dari model konvensional, yaitu 77,97 > 66,75 Hasil pengujian hipotesis menunjukkan nilai $t_{\text {hitung }}>t_{\text {tabel }}(9.081>1,997)$, sehingga disimpulkan bahwa model pembelajaran PBL berbasis CLIS memiliki pengaruh yang lebih baik dari model konvensional, terhadap motivasi belajar peserta didik.
\end{abstract}

Kata kunci: problem based learning, children learning in science, motivasi belajar 


\section{PENDAHULUAN}

Fisika merupakan salah satu cabang ilmu pengetahuan alam yang mempelajari gejalagejala fisis yang terjadi di sekitar kita. Seperti ilmu pengetahuan lainnya, ilmu fisika didasarkan pada pengamatan ekperimental dan pengukuran kuantitatif. Tujuan utama fisika adalah mencari sejumlah hukum-hukum dasar yang mengatur berbagai fenomena alam dan menggunakan hukum-hukum tersebut untuk mengembangkan teori-teori yang dapat memprediksi hasil-hasil percobaan selanjutnya. Teori dasar yang digunakan dalam pengembangan teori sebagai jembatan antara teori dan percobaan menggunakan bahasa matematika.

Di dalam dunia pendidikan, fisika merupakan salah satu mata pelajaran yang dimasukkan pada kurikulum. Hakikat pembelajaran ini adalah tidak hanya menuntun peserta didik untuk mengetahui konsep terkait gejala fisis yang terjadi tetapi mampu membuktikan serta mengaplikasikan konsep yang telah mereka peroleh. Oleh karena itu, pada pelaksanaannya, peserta didik diarahkan untuk dapat memperoleh pengalaman secara langsung, sehingga mampu lebih memahami materi yang diperoleh.

Menurut Ismail (2017), penyelenggaraan mata pelajaran Fisika di SMA dimaksudkan sebagai wahana atau sarana untuk melatih para peserta didik agar dapat menguasai konsep dan prinsip Fisika, memiliki kecakapan ilmiah, memiliki keterampilan proses sains dan keterampilan berpikir kritis dan kreatif. Agar mata pelajaran Fisika dapat benar-benar berperan seperti demikian, maka tak dapat ditawar lagi bahwa pembelajaran Fisika harus dikonstruksi sedemikian rupa, sehingga proses pendidikan dan pelatihan berbagai kompetensi tersebut dapat benar- benar terjadi dalam prosesnya.

Proses pembelajaran pada kurikulum 2013 diselenggarakan secara interaktif, inspiratif, menyenangkan, menantang, memotivasi peserta didik untuk berpartisipasi aktif, serta memberikan ruang yang cukup bagi prakarsa, kreativitas dan kemandirian sesuai dengan bakat, minat dan perkembangan fisik serta psikologis peserta didik. Hal ini sesuai dengan tema pengembangan kurikulum 2013 yaitu kurikulum yang dapat menghasilkan insan Indonesia yang produktif, kreatif, inovatif, efektif melalui penguatan sikap, keterampilan dan pengetahuan yang terintegritas. Sehubungan dengan itu, kurikulum 2013 menerapkan pendekatan saintifik dalam proses pembelajaran (Azmi dkk, 2016).

Beragam model pembelajaran yang dapat digunakan untuk menyampaikan materi pelajaran, khususnya pelajaran fisika di tingkat SMA. Selama ini pembelajaran di sekolah menggunakan pembelajaran langsung yang memusatkan informasi pada satu sisi yaitu guru. Hasil yang diperoleh dari model pembelajaran yang selama ini digunakan cukup memuaskan yang dapat dilihat dari tingkat kelulusan peserta didik. Tetapi hasil yang seperti itu tidak dapat dipertahankan dengan model yang sama, sehbingga model pembelajaran perlu dikombinasikan dengan model atau metode yang lain. Model pembelajaran yang dipilih sebaiknya mampu menciptakan interaksi dua arah, dari guru ke peserta didik, dan dari peserta didik ke guru.

Salah satu model pembelajaran saintifik yang dapat dijadikan sebagai alternatif dalam pembelajaran fisika adalah model pembelajaran Problem Based Learning (PBL). Menurut Yoannita dkk (2016), ada beberapa model pembelajaran yang dapat meningkatkan keaktifan dan motivasi peserta didik dalam belajar. Salah satunya adalah model pembelajaran yang menitik beratkan pada pemecahan masalah sehari-hari yaitu model Problem Based Learning. Problem based learning adalah model pembelajaran yang mendorong peserta didik untuk belajar dan bekerjasama dalam kelompok untuk mencari penyelesaian masalah-masalah di dunia nyata. Peserta didik yang telah melalui proses pembelajaran menggunakan model problem based learning dapat mengerjakan ujian akhir atau tes dengan lebih santai dan tidak tegangkarena mereka telah terbiasa menghadapi masalah masalah dalam proses pembelajaran. Perasaan santai dan tidak tegang dapat memicu peserta didik untuk berpikir lebih efektif dan 
efisien sehingga hasil tes yang mereka dapatkan menjadi lebih baik.

Menurut Sujana dalam Abdurrozak dkk (2016), "PBL adalah suatu pembelajaran yang menyuguhkan berbagai situasi bermasalah yang autentik dan berfungsi bagi peserta didik, sehingga masalah tersebut dapat dijadikan batu loncatan untuk melakukan investigasi dan penelitian". Maka dari itu PBL merupakan sebuah pembelajaran yang menuntut peserta didik untuk mengkonstruksi pengetahuan mereka sendiri melalui permasalahan. Problem Based Learning (PBL) merupakan suatu pembelajaran yang menekankan pada pemberian masalah nyata dalam kehidupan sehari-hari yang harus dipecahkan oleh peserta didik melalui investigasi mandiri untuk mengasah kemampuan berpikir kreatif dalam pemecahan masalah agar terbentuk solusi dari permasalahan tersebut sebagai pengetahuan dan konsep yang esensial dari pembelajaran.

Model problem based learning atau model pembelajaran berbasis masalah adalah model yang menekankan pada pembelajaran berbasis student centered, yang dapat memberdayakan peserta didik untuk melakukan penyelidikan, mengintegrasikan teori dan praktik, menerapkan pengetahuan dan keterampilannya untuk mengembangkan penemuan solusi atau pemecahan masalah tertentu. Model problem based learning terdiri dari 5 fase pembelajaran yang meliputi: orientasi peserta didik terhadap masalah, organisasi peserta didik, membantu investigasi mandiri atau kelompok, mengembangkan dan mempresentasikan hasil, menganalisis dan mengevaluasi proses pemecahan masalah (Nurqomariah dkk, 2015).

Azmi dkk (2016) menambahkan bahwa model problem based learning merupakan sebuah model pembelajaran yang menyediakan pengalaman autentik yang mendorong peserta didik untuk belajar aktif, mengkonstruksi pengetahuan, dan mengintegrasikan konteks belajar di sekolah dan belajar di kehidupan nyata secara alamiah. Model problem based learning merupakan suatu model pembelajaran yang didasarkan pada banyaknya permasalahan yang membutuhkan penyelidikan autentik yakni penyelidikan yang membutuhkan penyelesaian nyata dari permasalahan nyata.
Inti dari pembelajaran berbasis masalah ini adalah menggunakan masalah dunia nyata sebagai konteks bagi peserta didik untuk berpikir kritis dan pemecahan masalah. Dalam pembelajaran berbasis masalah peserta didik terlibat aktif dalam penyelidikan untuk pemecahan masalah yang mengintegrasikan keterampilan dan konsep dari berbagai isi materi pelajaran, mensintesa, dan mempresentasikan penemuannya kepada orang lain. Dalam proses penyelesaian masalah tersebut guru meminta peserta didik untuk mengumpulkan informasi, melakukan suatu penyelidikan, diskusi dan sebagainya sehingga secara tidak langsung dapat meningkatkan kompetensi kinerja ilmiah atau disebut dengan keterampilan proses sains peserta didik (Putra dkk, 2016).

Kelebihan PBL adalah: 1) peserta didik akan terbiasa menghadapi masalah dan merasa tertantang untuk menyelesaikan masalah, tidak hanya terkait dengan pembelajaran dalam kelas, tetapi juga menghadapi masalah yang ada dalam kehidupan sehari-hari, 2) memupuk solidaritas sosial dengan terbiasa berdiskusi dengan temanteman sekelompok kemudian berdiskusi dengan teman sekelasnya, 3) semakin mengakrabkan guru dengan peserta didik, 4) karena ada kemungkinan suatu masalah harus diselesaikan peserta didik melalui eksperimen, hal ini juga akan membiasakan peserta didik dalam menerapkan metode eksperimen. Pada prinsipnya PBL menekankan pada peningkatan dan perbaikan cara belajar dengan tujuan untuk menguatkan konsep dalam situasi nyata, mengembangkan keterampilan berpikir tingkat tinggi, keterampilan memecahkan masalah, meningkatkan keaktifan belajar peserta didik, mengembangkan keterampilan membuat keputusan, menggali informasi, meningkatkan percaya diri, tanggung jawab, kerjasama dan komunikasi. Proses pembelajaran dengan model PBL sangat menunjang pembangunan keterampilan dalam mengatur diri sendiri (self directed), kolaboratif, keterampilan berpikir tingkat tinggi yang di dalamnya termasuk berpikir kreatif, cakap menggali informasi yang semuanya diperlukan di dunia kerja (Supiandi dkk, 2016).

Sebagaimana yang telah diuraikan pada permasalahan sebelumnya, bahwa untuk mempertahankan kualitas pembelajaran, maka 
model pembelajaran yang digunakan perlu disandingkan dengan metode pemebelajaran yang sejalan. Hal ini bertujuan untuk mencegah terjadinya kejenuhan di dalam proses pembelajaran tersebut, sehingga kualitas pembelajaran dapat dipertahankan. Salah satu metode pembelajaran yang dapat disandingkan dengan PBL adalah metode pembelajaran children learning and science (CLIS). Menurut Ismail (2015), salah satu pembelajaran yang dipandang dapat membantu dan memfasilitasi untuk memudahkan peserta didik dalam menguasai sains fisika dan berlatih mengembangkan keterampilan proses sains dan penguasaan konsep adalah metode pembelajaran children learning in science (CLIS). Metode pembelajaran CLIS adalah kerangka berpikir untuk menciptakan lingkungan yang memungkinkan terjadinya kegiatan belajar mengajar yang melibatkan peserta didik dalam kegiatan pengamatan dan percobaan.

Arum et al dalam Laili (2015) menjelaskan bahwa metode CLIS merupakan salah satu model pembelajaran yang strateginya berorientasi pada konstruktivisme. Metode pembelajaran CLIS pada prinsipnya merupakan pengembangan dari model pembelajaran generatif. Metode CLIS lebih menekankan pada kegiatan peserta didik untuk menyempurnakan dalam mendapatkan ide-ide, menyesuaikan dengan ilmu pengetahuan yang ada, memecahkan dan mendiskusikan masalahmasalah yang muncul sehingga peserta didik dapat mengemukakan pendapatnya sendiri, sebelum guru memberikan penyempurnaan ideide ilmiah, peserta didik dituntun menuju pembangunan ide baru atau ide yang lebih ilmiah.

Samatowa dalam Astiti (2017) menyatakan model pembelajaran children learning in science terdiri atas lima langkah utama, yakni orientasi (orientation), pemunculan gagasan (elicitation of ideas), penyusunan ulang gagasan (restructuring of ideas), penerapan gagasan (application of ideas), dan pemantapan gagasan (review change in ideas). Langkah penyusunan ulang gagasan (restructuring of ideas) masih dibedakan atas tiga bagian, yaitu pengungkapan dan pertukaran gagasan (clarification and exchange), pembukaan pada situasi konflik (exposure to conflict situation), dan konstruksi gagasan baru dan evaluasi (construction of new ideas and evaluation).

Sejalan dengan pendapat Samatowa, Ajul (2019) menjelaskan bahwa metode pembelajaran CLIS merupakan metode pembelajaran yang menuntut siswa agar mengembangkan gagasannya tentang suatu masalah tertentu dalam proses pembelajaran dan memberikan siswa kesempatan untuk mengungkapkan ide atau gagasannya secara menyeluruh dan dapat mengembangkannya melalui percobaan dan peran guru sebagai fasilitator. Pembelajaran konstruktivis ini mempunyai pengaruh yang sangat penting dalam mengembangkan kemampuan berpikir siswa dan dapat membangun pengetahuannya sendiri. Metode pembelajaran CLIS memberikan pengaruh yang baik terhadap proses pembelajaran dan dapat meningkatkan hasil belajar siswa, hal tersebut didukung hasil penelitian. Metode pembelajaran CLIS terdiri atas lima tahapan utama yaitu orientasi, pemunculan gagasan, penyusunan ulang gagasan, penerapan gagasan, dan pemantapan gagasan.

Merujuk pada langkah-langkah metode CLIS, maka sangatlah jelas bahwa metode CLIS cocok untuk disandingkan dengan model pembelajaran PBL. Namun, proses pembelajaran dengan model PBL yang disandingkan dengan metode CLIS tentunya harus didukung oleh faktor yang berasal dari dalam diri peserta didik yang mengikuti proses pembelajaran tersebut. Salah satu faktornya adalah adanya motivasi peserta didik. Motivasi belajar merupakan dorongan yang timbul dari dalam diri seseorang untuk melakukan suatu proses demi mencapai tujuan tertentu. Menurut Sardiman dalam Doyan (2018), motivasi adalah perubahan energi dalam diri seseorang yang ditandai dengan munculnya "feeling" dan didahului dengan tanggapan terhadap adanya tujuan.

Rambega (2016) menambahkan bahwa faktor penunjang kesuksesan belajar adalah motivasi. Faktor tersebut merupakan pendorong/pemberi semangat untuk memperoleh kesuksesan. Dengan motivasi yang kuat dapat membuat seorang pelajar sanggup bekerja ekstra keras untuk mencapai sesuatu. Olehnya itu motivasi 
belajar siswa baik dari guru dan dari dirinya sendiri harus dapat diketahui.

Motivasi dapat diartikan sebagai kekuatan (energi) seseorang yang dapat menimbulkan tingkat kemauan dalam melaksanakan suatu kegiatan. Kemauan baik yang bersumber dari dalam diri individu itu sendiri (motivasi intrinsik) maupun dari luar individu (motivasi ekstrinsik). Seberapa kuat motivasi yang dimiliki individu dapat menentukan kualitas perilaku yang ditampilkannya, baik dalam konteks belajar, bekerja maupun dalam kehidupan lainnya (Suprihatin, 2015).

Maslow dalam Cleopatra (2015), mengatakan bahwa motivasi merupakan energi dalam diri seseorang yang ditandai oleh feeling dan didahului oleh tanggapan terhadap tujuan. Menurutnya motivasi mengadung tiga elemen yaitu: a) motivasi yang mengawali perubahan energi pada diri setiap individu dan berkaitan dengan perubahan tersebut maka tampak pada kegiatan fisik, (b) motivasi oleh karena adanya rasa (feeling), dan afeksi seseorang yang erat hubungannya dengan kondisi kejiwaan, afeksi dan emosi yang menentukan tingkah laku manusia, dan (c) motivasi yang terangsang karena adanya tujuan. Oleh karena itu maka dikatakan bahwa motivasi sangat erat kaitannya dengan kebutuhan.

Selama ini, di dalam proses pembelajaran Fisika, tidak semua peserta didik menunjukkan motivasinya dalam belajar fisika. Berbagai alasan yang diutarankan oleh peserta didik, antara lain adalah karena fisika merupakan mata pelajaran yang sulit, terlalu banyak rumus yang harus dihafalkan, ataupun contoh soal yang diperoleh berbeda dengan soal latihan yang diberikan oleh guru. Menurut peneliti, berbagai alasan yang muncul dari benak peserta didik disebabkan karena tidak terlibatnya peserta didik secara langsung dalam proses pembelajaran. Berkaitan dengan permasalahan inilah, maka dirasa perlu untuk melakukan penelitian yang menerapakan pembelajaran PBL berbasis CLIS, yang melibatkan peserta didik secara langsung dalam pembelajarannya. Tentunya, harapan dari penerapan model pembelajaran PBL berbasis CLIS adalah dapat menumbuhkan motivasi belajar peserta didik serta mengubah paradigmanya tentang pelajaran fisika.
Tujuan dari penelitian ini untuk mengetahui pengaruh model PBL berbasis CLIS terhadap motivasi belajar peserta didik.

\section{METODE}

Jenis penelitian ini adalah penelitian quasi eksperimen. Desain penelitian yang digunakan adalah The matching only post test group design yaitu suatu teknik untuk penyamaan kelompok pada satu atau lebih variabel yang telah diidentifikasi peneliti sebagai berhubungan dengan performansi pada variabel terikat. Dengan kata lain, untuk setiap subjek yang ada, peneliti berupaya menemukan subjek yang lain yang sama atau skor yang sama pada variabel kontrol (Fraenkael et al, 2012: 275).

Populasi dalam penelitian ini adalah seluruh peserta didik kelas XII IPA SMA Negeri 3 Kab. Pinrang yang berjumlah 136 orang dan tersebar pada 4 rombel kelas. Sampel penelitian berjumlah 66 orang yang diperoleh dari dua kelas populasi, menggunakan teknik random kelas yang dipadu dengan teknik matching sample. Prosedur pemilihan sampel dengan teknik tersebut yaitu terlebih dahulu memilih 2 kelas secara random atau acak dari 4 kelas yang ada pada populasi. Setelah itu, masing-masing peserta didik yang ada pada dua kelas yang terpilih kemudian saling dipasangkan (matching) berdasarkan nilai fisika sebelumnya. Dua orang peserta didik yang memiliki nilai yang sama dinyatakan sebagai 1 pasangan sampel. Prosedur ini dilakukan hingga diperoleh 33 pasangan sampel, sehingga total sampel keseluruhan adalah 66 orang, 33 di kelas eksperimen dan 33 orang di kelas kontrol.

Prosedur penelitian ini yaitu dengan memberikan perkuan kepada dua kelas yang terpilih menjadi kelompok sampel. Satu kelas diajar dengan mengunakan model PBL berbasis CLIS (disebut dengan kelas eksperimen) dan satu kelas yang lain diajar dengan model pembelajaran konvensional (disebut dengan kelas kontrol). Di akhir perlakuan, dilakukan pengukuran motivasi belajar terhadap peserta didik dari kedua kelas.

Instrumen yang digunakan untuk mengumpulkan data motivasi peserta didik adalah angket motivasi belajar yang diadaptasi dari Ria Rizty Yani, M.Pd., yang telah divalidasi sebelumnya dengan nilai kevalidan sebesar 0,82 
dan berarti kevalidan tinggi. Angket memuat pernyataan-pernyataan yang disesuaikan dengan indikator motivasi belajar dan menggunakan skala likert.

Teknik analisis data yang digunakan terdiri atas teknik analisis deskriptif dan analisis inferensial. Teknik analisis data deskriptif terdiri atas mean, standar deviasi, nilai maksimum, nilai minimum, varians, serta pengkategorian tingkat motivasi peserta didik. Terkhusus untuk pengkategorian motivasi belajar, digunakan rumus proporsi (Siregar, 2014: 112), sebagai berikut:

$$
P=\frac{f}{N} \times 100 \%
$$

Dimana, $\mathrm{P}$ adalah persentase proporsi, $f$ adalah frekuensi, dan $N$ adalah jumlah responden atau subjek penelitian. Rentang kategori motivasi belajar peserta didik akan disesuaikan dengan rentang pada tabel 1 .

Tabel 1. Rentang kategori Motivasi belajar

\begin{tabular}{cc}
\hline Rentang nilai & Kategori \\
\hline $\mathbf{2 5 - 3 9}$ & Sangat rendah \\
$\mathbf{4 0 - 5 4}$ & Rendah \\
$\mathbf{5 5 - 6 9}$ & Sedang \\
$\mathbf{7 0 - 8 4}$ & Tinggi \\
$\mathbf{8 5 - 1 0 0}$ & Sangat tinggi \\
\hline
\end{tabular}

(Widyoko, 2011: 237)

Sementara itu, teknik analisis inferensial yang digunakan adalah uji-t dua sampel independent dengan taraf $\alpha=0.05$. Analisis ini digunakan untuk menguji signifikansi perbedaan dari variabel yang diukur. Dengan kata lain, analisis ini digunakan untuk menguji hipotesis penelitian ayng disajikan pada penelitian ini.

$$
t_{\text {hitung }}=\frac{\overline{\mathrm{x}}_{1}-\overline{\mathrm{x}}_{2}}{\sqrt{\frac{\left(\mathrm{n}_{1}-1\right) \mathrm{S}_{1}^{2}+\left(\mathrm{n}_{2}-1\right) \mathrm{S}_{2}^{2}}{\mathrm{n}_{1}+\mathrm{n}_{2}-2}\left(\frac{1}{\mathrm{n}_{1}}+\frac{1}{\mathrm{n}_{2}}\right)}}
$$

Dimana, jika nilai $t_{\text {hitung }}>t_{\text {tabel }}$ pada taraf signifikan 0,05 maka Ho ditolak dan Ha diterima (Siregar, 2014: 238).

Tabel 2. Nilai motivasi belajar peserta didik

\begin{tabular}{cccc}
\hline \multicolumn{2}{c}{ Kelas XI.IPA3 (Kelas Eksperimen) } & \multicolumn{2}{c}{ Kelas XI.IPA4 (Kelas Kontrol) } \\
\hline Rentang & Frekuensi & Rentang & Frekuensi \\
\hline $69-73$ & 9 & $57-60$ & 10 \\
$74-78$ & 6 & $61-64$ & 9 \\
$79-83$ & 15 & $65-68$ & 8 \\
$84-88$ & 2 & $69-72$ & 4 \\
$89-93$ & 1 & $73-76$ & 33 \\
\hline Jumlah & 33 & & \\
\hline
\end{tabular}

Berdasarkan tabel 2, dapat ditunjukkan bahwa nilai motivasi perserta didik dari kelas eksperimen rata-rata berada pada rentang 79-83 dengan frekuensi 15 orang peserta didik. Sementara pada kelas kontrol, rata-rata peserta

\section{HASIL DAN PEMBAHASAN}

\section{Gambaran Motivasi Belajar Peserta Didik}

Penelitian ini dilaksanakan dengan cara memberikan perlakuan yang berbeda pada dua kelas yang telah terpilih sebagai kelompok sampel, yaitu model PBL berbasis CLIS dan model konvensional. Setelah kedua kelas diberikan perlakuan, selanjutnya memberikan angket motivasi belajar kepada peserta didik dari dua kelas tersebut untuk memperoleh data motivasi belajar.

Nilai motivasi belajar peserta didik dari kedua kelas, setelah dilakukan pengukuran menggunakan angket, disajikan pada tabel 2 . didik memiliki nilai motivasi belajar pada rentang 61-64 dengan frekuensi 10 peserta didik.

Tabulasi nilai pada tabel 2 dijadikan acuan dalam analisis deskriptif, yang hasilnya dapat ditunjukkan pada tabel 3 . 
Karst : Jurnal Pendidikan Fisika dan Terapannya

Volume 4 | Nomor 2 | 46

p-ISSN: 2622-9641 e-ISSN: 2655-1276

Tabel 3. Hasil analisis deskriptif untuk nilai motivasi belajar

\begin{tabular}{lcc}
\hline \multirow{2}{*}{ Parameter Statistik Deskriptif } & \multicolumn{2}{c}{ Nilai } \\
\cline { 2 - 3 } & XI.IPA 3 (Eksperimen) & XI.IPA 4 (Kontrol) \\
\hline Nilai Maksimum & 92 & 76 \\
Nilai Minimum & 69 & 57 \\
Rata-rata & 77,97 & 66,75 \\
Standar Deviasi & 5,29 & 4,89 \\
Varians & 28,03 & 23,93 \\
N & 33 & 33 \\
\hline
\end{tabular}

Hasil analisis deskriptif pada tabel 3 memberikan informasi bahwa jumlah sampel pada kelas eksperimen dan kelas kontrol sebanyak 33 orang. Nilai tertinggi motivasi belajar peserta didik pada kelas eksperimen adalah 92 dan pada kelas kontrol sebesar 76 . Sementara nilai terkecil adalah 69 pada kelas eksperimen dan 57 pada kelas kontrol. Jika merujuk pada nilai rata-rata (mean), dapat ditunjukkan bahwa motivasi belajar peserta didik pada kelas eksperimen lebih tinggi dari kelas kontrol, yaitu dengan nilai rata-rata masingmasing sebesar 77,97 dan 66,75. Berdasarkan nilai rata-ratanya, maka secara deskriptif dapat ditunjukkan bahwa peserta didik yang diajar dengan model PBL berbasis CLIS (kelas eksperimen) memiliki motivasi yang lebih tinggi dari peserta didik yang diajar dengan model konvensional (kelas kontrol), dalam mengikuti pembelajaran fisika.

Tingkatan motivasi belajar peserta didik, baik pada kelas eksperimen maupun kelas kontrol dapat disajikan dalam bentuk rentang kategori motivasi belajar. Hasil pengkategorian motivasi belajar dari kedua kelas dapat ditunjukkan pada tabel 4.

Tabel 4. Tingkat motivasi belajar peserta didik

\begin{tabular}{|c|c|c|c|c|c|}
\hline \multirow{2}{*}{ Rentang } & \multicolumn{2}{|c|}{ Kelas XI.IPA3 (Kelas Eksperimen) } & \multicolumn{2}{|c|}{ Kelas XI.IPA4 (Kelas Kontrol) } & \multirow{2}{*}{$\begin{array}{l}\text { Kategori Motivasi } \\
\text { Belajar }\end{array}$} \\
\hline & frekuensi & $\%$ & frekuensi & $\%$ & \\
\hline $25-39$ & 0 & 0 & 0 & 0 & Sangat rendah \\
\hline $40-54$ & 0 & 0 & 0 & 0 & Rendah \\
\hline $55-69$ & 1 & 3 & 21 & 63,6 & Sedang \\
\hline $70-84$ & 29 & 87,9 & 12 & 36,4 & Tinggi \\
\hline $85-100$ & 3 & 9,1 & 0 & 0 & Sangat tinggi \\
\hline Jumlah & 33 & 100 & 33 & 100 & \\
\hline
\end{tabular}

Informasi yang disajikan pada tabel 4, juga dapat dijadikan dasar untuk menunjukkan adanya perbedaan motivasi belajar peserta didik dari kedua kelas. Nampak pada tabel 4, rata-rata peserta didik pada kelas eksperimen memiliki tingkat motivasi belajar yang tinggi, yaitu sebanyak 29 orang dari 33 orang denagn presentase $87,9 \%$, yang memiliki skor motivasi yang berada pada rentang tinggi. Sementara pada kelas kontrol, rata-rata tingkat motivasi peserta didik berada pada kategori sedang, yaitu sebanyak 21 orang dari 33 orang dengan presentase $63,6 \%$.

\section{Uji Perbedaan Motivasi Belajar Peserta Didik}

Uji perbedaan atau uji hipotesis dalam penelitian ini digunakan untuk mengetahui signifikansi perbedaan motivasi belajar peserta didik dari dua kelas yang dibandingkan, sehingga dari perbedaan tersebut dapat diketahui variabel mana yang lebih berpengaruh terhadap motivasi belajar peserta didik. Berdasarkan hasil analisis inferensial menggunakan uji-t dua sampel independent diperoleh hasil sebagaimana disajikan pada tabel 5 . 
Karst : Jurnal Pendidikan Fisika dan Terapannya

Volume 4 | Nomor 2 | 47

p-ISSN: 2622-9641 e-ISSN: 2655-1276

Tabel 5. Hasil analisis uji hipotesis menggunakan uji-t dua sampel independent

\begin{tabular}{|c|c|c|c|c|c|c|}
\hline \multicolumn{7}{|c|}{ Independent Samples Test } \\
\hline & & \multicolumn{2}{|c|}{$\begin{array}{c}\text { Levene's Test for Equality of } \\
\text { Variances }\end{array}$} & \multicolumn{3}{|c|}{ t-test for Equality of Means } \\
\hline & & $\mathrm{F}$ & Sig. & $\mathrm{t}$ & df & Sig. (2-tailed) \\
\hline Motivasi & $\begin{array}{l}\text { Equal variances } \\
\text { assumed }\end{array}$ & .801 & .374 & 9.081 & 64 & .000 \\
\hline Belajar & $\begin{array}{l}\text { Equal variances not } \\
\text { assumed }\end{array}$ & & & 9.081 & 63.145 & .000 \\
\hline
\end{tabular}

Berdasarkan tabel 5, diperoleh informasi yang berkaitan dengan homogenitas data dan signifikansi perbedaan variabel motivasi dari kedua kelas yang dibandingkan. Pengujian homogenitas data dapat dilihat pada kolom Levene's Test for Equality of Variances, dengan nilai signifikansi yang diperoleh sebesar 0.374. Nilai ini lebih besar dari taraf $\alpha=0.05$, sehingga disimpulkan bahwa kedua kelas memiliki varians yang sama atau homogen.

Sementara itu, uji hipotesis atau uji signifikansi perbedaan ditunjukkan pada kolom t-test for Equality of Means. Untuk derajat kebebasan $(\mathrm{df})=64$, diperoleh nilai $t_{\text {hitung }}$ sebesar 9.081 dengan signifikansi 0.000. Nilai $\mathrm{t}_{\text {tabel }}$ pada taraf $\alpha=0.05 \mathrm{dan} \mathrm{df}=64$, diperoleh nilai $t_{\text {tabel }}=1,997$ pada tabel harga kritis untuk $t$. Jika kedua nilai $\mathrm{t}$ dibandingkan, maka dapat ditunjukkan bahwa $t_{\text {hitung }}>t_{\text {tabel }}(9.081>1.997)$, selain itu nilai sig. (2-tailed) yang diperoleh pada tabel 5 lebih kecil dari taraf $\alpha=0.05$. Kedua hasil ini memberikan kesimpulan bahwa terdapat perbedaan motivasi belajar yang signifikan antara peserta didik yang diajar dengan model PBL berbasis CLIS dan model konvensional.

\section{PEMBAHASAN}

Hasil penelitian yang diperoleh beserta dengan hasil pengolahan data menunjukkan bahwa motivasi belajar peserta didik pada kelas eksperimen lebih baik dari kelas kontrol. Dengan kata lain, model PBL berbasis CLIS memberikan pengaruh yang lebih baik dari pada model pembelajaran kovensional terhadap motivasi belajar peserta didik, sebagaimana yang ditunjukkan dari nilai rata-rata kedua kelas dan pengujian signifikansi menggunakan uji-t.
Adanya perbedaan pengaruh dari kedua model pembelajaran yang diterapkan terhadap motivasi belajar peserta didik dari msingmasing kelas yang dibandingkan, tidak terlepas dari prinsip kedua model pembelajaran. Suasana pembelajaran dengan model PBL berbasis CLIS yang diterapkan pada kelas eksperimen, lebih menekankan pada keterlibatan peserta didik secara langsung pada prosesnya, sehingga tercipta interaksi dua arah, antara guru dan peserta didik. Sementara itu, pembelajaran dengan model konvensional (model pembelajaran langsung) lebih menciptakan suasana yang satu arah saja, dengan guru sebagai pusat pembelajaran dibandingkan peserta didik.

Pembelajaran yang berlandas pada kurikulum 2013 memang sudah seharusnya menerapkan model pembelajaran yang dapat melibatkan peserta didik secara langsung pada prosesnya. Maka dalam hal ini, peran guru sangatlah dibutuhkan untuk meciptakan suasana pembelajaran yang efektif. Menurut Hartini (2014), dalam mempelajari fisika, peran guru dalam proses belajar tersebut sangat diperlukan. Salah satu cara guru dalam mengembangkan pola berpikir siswa adalah dengan memberikan alternatif pilihan untuk menggunakan model pembelajaran yang lebih tepat dalam pembelajaran fisika, dengan model pembelajaran yang tepat memungkinkan siswa lebih mudah dalam memahami fisika. Hal ini bertujuan agar peserta didik dapat menemukan arti dari pembelajaran tersebut dan dengan sendirinya mampu menumbuhkan motivasi belajar peserta didik.

Menurut Lestari (2012), motivasi dalam belajar dapat menumbuhkan hasrat dan keinginan untuk belajar yang lebih bermakna. Kegiatan pembelajaran yang telah dipersiapkan 
guru diharapkan dapat berjalan sesuai dengan apa yang telah direncanakan dan tujuan yang ingin dicapai. Salah satu tujuan pembelajaran itu adalah adanya perubahan tingkah laku yang berupa sikap ilmiah siswa dan peningkatan prestasi belajar. Upaya yang dilakukan siswa maupun guru untuk mencapai tujuan tersebut terdapat faktor motivasi yang berasal dari dalam diri siswa seperti yang telah dijelaskan sebelumnya, di mana hal ini tidak bisa diabaikan oleh seorang guru. Siswa yang telah termotivasi untuk belajar akan dapat menunjukan kreatifitasnya secara lebih mendalam saat mengikuti pelajaran di kelas. Peranan yang khas dari motivasi adalah dalam hal menumbuhkan gairah, merasa senang dan semangat untuk belajar.

Oleh karena itu, sangatlah memungkinkan jika model PBL berbasis CLIS memberikan pengaruh yang signifikan terhadap motivasi belajar peserta didik, sebab dalam pembelajaran ini, peserta didik terlimbat langsung.

Arends (2007) dalam Tanti (2018) menyatakan bahwa model pembelajaran berbasis masalah adalah model pembelajaran dengan pendekatan pembelajaran pada masalah autentik dan bermakna kepada siswa, sehingga siswa dapat menyusun pengetahuannya sendiri, menumbuhkembangkan keterampilan yang lebih tinggi dan inkuiri, memandirikan siswa, dan meningkatkan kepercayaan diri sendiri. Model pembelajaran berbasis masalah bercirikan penggunaan masalah kehidupan nyata untuk meningkatkan keterampilan berpikir kritis dan menyelesaikan masalah, serta mendapatkan pengetahuan konsep-konsep penting. Model pembelajaran berbasis masalah atau problem based learning mengutamakan proses belajar dimana guru harus memfokuskan diri membantu siswa mencapai keterampilan mengarahkan diri.

Merujuk pada pendapat Arends, maka model PBL sangat cocok untuk peserta didik dalam menumbuhkan motivasi belajar. Faktor motivasi sendiri sangat diperlukan bagi peserta didik dalam mengikuti proses pembelajaran. Sebab, motivasi belajar merupakan dorongan dalam diri peserta didik untuk belajar. Tanpa adanya motivasi, maka peserta didik akan merasakan kesulitan dalam menemukan tujuan pembelajarannya.

Sementara itu, Pohan dkk (2020) menyatakan bahwa terdapat interaksi antara model problem based learning dengan motivasi belajar peserta didik dalam proses pembelajaran. Hal ini menunjukkan bahwa proses belajar dengan menggunakan model PBL mendukung peningkatan motivasi sehingga jika motivasi meningkat maka hasil dan tujuan pembelajaran lebih mudah untuk dicapai.

Pendekatan PBL diyakini sebagai pendekatan pembelajaran yang efektif yang mendorong siswa sebagai pembelajar mandiri. PBL juga mendukung pengembangan keterampilan berpikir kritis, kepemimpinan, dan kerja sama tim. Tinjauan dan meta-analisis kami menyajikan bukti bahwa penggunaan PBL dapat meningkatkan pemikiran kritis mahasiswa keperawatan bila dibandingkan dengan kuliah tradisional (Kong et al, 2014).

Selain itu, PBL menantang siswa untuk memecahkan masalah otentik dalam pengaturan yang kaya informasi. Mereka dapat membangun solusi mereka sendiri yang berkontribusi pada pengalaman yang paling efektif seperti metode, proses dan epistemologi disiplin. Namun, beberapa orang menyatakan bahwa semua pencarian berbasis masalah membuat kinerja berpikir menjadi tinggi. Beban berpikir tingkat tinggi tidak mengakibatkan akumulasi pengetahuan dalam long term memory karena proses berpikir digunakan untuk mencari solusi masalah sehingga tidak dapat digunakan untuk belajar. Juga tujuannya harus mengajar disiplin dengan penyelidikan daripada sebagai penyelidikan. Akhirnya ditunjukkan bahwa beberapa peserta yang dilatih dalam PBL tidak dapat memperoleh penalaran yang diarahkan ke depan tetapi mempertahankan pola penalaran yang diarahkan ke belakang. Ini dapat menunda pengembangan pola penalaran ke depan (Birgili, 2015).

Keefektifan proses pembelajaran PBL pada penelitian ini, dalam menumbuhkan motivasi belajar peserta didik tidak terlepas dari kombinasinya dengan metode CLIS. Metode ini lebih memberikan ruang kepada peserta didik untuk lebih kreatif dalam pembelajarannya. 
Pemberian ruang belajar untuk menemukan hakikat pembelajarannya, menjadikan peserta didik menjadi lebih termotivasi dalam mengikuti pembelajaran.

Paramata et al (2021) menjelaskan bahwa kesulitan siswa dalam mempelajari IPA terjadi karena pelajaran tergantung pada bagaimana guru mengajarkan mata pelajaran yang bersangkutan kepada siswa. Guru hendaknya mengubah rasa takut anak terhadap pelajaran IPA menjadi senang untuk membangkitkan minat dan keaktifan siswa dalam mengikuti pelajaran. Banyak cara yang dapat dilakukan oleh seorang guru untuk menyampaikan materi pelajaran yang dapat membuat siswa merasa senang, termasuk menggunakan model atau metode dalam pembelajaran. Salah satu metode pembelajaran yang digunakan adalah metode pembelajaran Children Learning In Science (CLIS).

Menurut Asih (2014), metode pembelajaran CLIS merupakan metode pembelajaran yang berusaha mengembangkan ide atau gagasan siswa tentang suatu masalah tertentu dalam pembelajaran serta mengkontruksi ide atau gagasan berdasarkan percobaan. Model pembelajaran ini, siswa diberi kesempatan untuk mengungkapkan, membandingkan, mendiskusikan, merekontruksidan serta mengaplikasikan gagasan tentang topik yang dibahas dalam pembelajaran. Tujuan model pembelajaran Children Learning In Science (CLIS) adalah memberi kesempatan siswa untuk mengungkapkan berbagai gagasan tentang topik yang dibahas dalam pembelajaran. Lalu mengungkapkan gagasan tersebut serta membandingkan dan mendiskusikanaya dengan siswa lainnya untuk menyamakan presepsi. Selanjutnya siswa diberi kesempatan merekonstruksi gagasan tersebut setelah membandingkan gagasan tersebut hasil pengamatan atau percobaan. Disamping itu, siswa juga menerapkan hasil rekontruksi gagasan dalam situasi baru.

Samatowa dalam Astiti (2017) mengemukakan bahwa metode CLIS menuntun "siswa yang konsepsi awalnya tidak konsisten dengan konsep ilmiah sadar akan mengubah konsepsi awalnya menjadi konsep ilmiah".
Oleh karena itu, dalam kegiatan pembelajaran siswa tidak hanya diberikan hafalan dan penekanan pada penguasaan konsep semata tetapi juga diberikan kesempatan untuk mengembangkan sikap ingin tahu melalui percobaan atau observasi.

Dengan demikian, jelaslah bahwa model PBL berbasis CLIS memberikan pengaruh yang lebih baik terhadap motivasi belajar peserta didik jika dibandingkan dengan model konvensional. Dengan kata lain, pada pembelajaran dengan model PBL berbasis CLIS, peserta didik akan mendapatkan lebih banyak ruang untuk terlibat secara langsung, sehingga dengan leluasa mampu mengembangkan potensi dalam dirinya.

Hasil penelitian ini sejalan dengan penelitian yang dilakukan oleh Asril (2019). Hasil penelitiannya menunjukkan bahwa model PBL berpengaruh terhadap hasil belajar peserta didik dan terdapat perbedaan motivasi belajar antara model PBL dan model konvensional.

Hasil yang sama juga ditunjukkan oleh penelitian Septian (2019), yang berjudul "Kemampuan Koneksi Matematik dan Motivasi Belajar Siswa dengan Mengunakan Model Problem-Based Learning (PBL) Berbantuan Geogebra di SMP". Hasil penelitiannya menunjukkan bahwa pembelajaran model PBL membuat siswa lebih mudah memahami materi yang diberikan dan siswa lebih termotivasi untuk belajar.

Hasil penelitian ini juga diperkuat oleh penelitian Tomas (2020) dengan judul "Pengaruh Penggunaan Model Problem Based Learning (PBL) terhadap Motvasi Belajar Matematika pada Siswa Kelas 4 SD”. Hasil penelitiannya menunjukkan bahwa terdapat pengaruh penggunaan model PBL terhadap motivasi belajar siswa.

Hasil penelitian Arief (2016) dengan judul "Meningkatkan Motivasi Belajar Melalui Pendekatan Problem-Based Learning (PBL)", menunjukkan hasil yang sama dengan hasil penelitian ini. Hasil yang ditunjukkan oleh penelitian Arief (2016) adalah bahwa peningkatan motivasi belajar pada kelas eksperimen dengan menggunakan pendekatan problem-based learning (PBL) secara signifikan lebih baik daripada kelas kontrol dengan 
Karst : Jurnal Pendidikan Fisika dan Terapannya Volume 4 | Nomor 2 | 54

p-ISSN: 2622-9641 e-ISSN: 2655-1276

menggunakan pendekatan konvensional. Pembelajaran dengan menggunakan pendekatan problem-based learning (PBL) mendapatkan respon yang positif dari siswa kelas eksperimen.

\section{PENUTUP}

Berdasarkan hasil penelitian ini maka dapat disimpulkan bahwa rata-rata skor motivasi belajar peserta didik yang diajar dengan model pembelajaran PBL berbasis CLIS lebih besar dari model konvensional, yaitu 77,97 > 66,75 Hasil pengujian hipotesis menunjukkan nilai $t_{\text {hitung }}>t_{\text {tabel }}(9.081>1,997)$, sehingga disimpulkan bahwa model pembelajaran PBL berbasis CLIS memiliki pengaruh yang lebih baik dari model konvensional, terhadap motivasi belajar peserta didik.

\section{DAFTAR PUSTAKA}

Abdurrozak, R., Jayadinata, A.K., 'Atun, I. 2016. Pengaruh Model Problem Based Learning terhadap Kemampuan Berpikir Kreatif Siswa. Jurnal Pena Ilmiah, 1(1): 871 - 880.

Ajul, L., Ain, N., Hudha, M.N. 2019. Metode Pembelajaran Children Learning in Science (CLIS): Efektifkah Meningkatkan Keterampilan Proses Sains dan Pemahaman Konsep Fisika? Jurnal Riset Pendidikan Fisika, 4(2) 98-103.

Arief, H.S., Maulana, Sudin, A. 2016. Meningkatkan Motivasi Belajar Melalui Pendekatan Problem-Based Learning (PBL). Jurnal Pena Ilmiah, 1(1): 141 - 150.

Asih, Fihrin, Kendek, Y. 2014. Penerapan Model Pembelajaran Children Learning in Science (CILS) untuk Meningkatkan Hasil Belajar Fisika pada Siswa Kelas XI SMA Negeri 8 Palu. Jurnal Pendidikan Fisika Tadulako (JPFT), 2(3) 20-23.

Asril, L.Y., Ain, N., Pratiwi, H.Y. 2019. Pengaruh Model Problem Based Learning (PBL) terhadap Motivasi dan Kemampuan Analisis Siswa. Makalah disajikan dalam Seminar Nasional Pendidikan, Program Studi Pendidikan Fisika FKIP ULM, Banjarmasin, 23 Maret 2019.
Astiti, N.P.M., Ardana, I.K., Wiarta, I.W. 2017. Pengaruh Model Pembelajaran Children Learning in Science Berbasis Budaya Penyelidikan Terhadap Kompetensi Pengetahuan IPA. Jurnal of Education Technology, 1(2) 86-93.

Azmi, M.K., Rahayu, S., Hikmawati. 2016. Pengaruh Model Problem Based Learning dengan Metode Eksperimen dan Diskusi Terhadap Hasil Belajar Fisika Ditinjau dari Sikap Ilmiah Siswa Kelas X MIPA SMA N 1 Mataram. Jurnal Pendidikan Fisika dan Teknologi, 2(2): 86-94.

Birgili, B. 2015. Creative and Critical Thinking Skills in Problem-based Learning Environments. Journal of Gifted Education and Creativity, 2(2): 71-80.

Cleopatra, M. 2015. Pengaruh Gaya Hidup dan Motivasi Belajar Terhadap Prestasi Belajar Matematika. Jurnal Formatif, 5(2): 168 181.

Doyan, A., Taufik, M., Anjani, R. 2018. Pengaruh Pendekatan Multi Representasi terhadap Hasil Belajar Fisika Ditinjau dari Motivasi Belajar Peserta Didik. Jurnal Penelitian Pendidikan IPA (JPPIPA), 4(1): 35 -45.

Fraenkel, J.R., Wallen, N.E., Hyun, H.H. (2012). How to Design and Evaluate Research in Education, Eighth Edition. New York: McGraw Hill.

Hartini, T.I., Kusdiwelirawan, A., Fitriana, I. 2014. Pengaruh Berpikir Kreatif dengan Model Problem

PETIK: Jurnal Pendidikan Informatika dan Komunikasi, 1(1) 19-25.

.2017. Penerapan Model Pembelajaran Children Learning In Science (CLIS) Berbantuan Multimedia Untuk Meningkatkan Keterampilan Proses Sains Siswa SMA pada Pokok Bahasan Fluida. JIPFRI: Jurnal Inovasi Pendidikan Fisika dan Riset Ilmiah, 1(2) 83-87.

Kong, L., N., Qin, B., Zhou, Y., Mou, S., Gao, H.,M. 2013. The effectiveness of problembased learning on development of nursing students' critical thinking: A systematic review and meta-analysis. International 
Karst : Jurnal Pendidikan Fisika dan Terapannya Volume 4 | Nomor $2 \mid 55$ p-ISSN: 2622-9641 e-ISSN: 2655-1276

Journal of Nursing Studies, 51(2014): 458 469.

Laili, Y.N., Mahardika, I.K., Ghani, A.A. 2015. Pengaruh Model Children Learning In Science(Clis) Disertai LKS Berbasis Multirepresentasi Terhadap Aktivitas Belajar Siswa dan Hasil Belajar Siswa dalam Pembelajaran Fisika di SMA Kabupaten Jember. Jurnal Pembelajaran Fisika, 4(2) 171-175.

Lestari, N.N.S. 2012. Pengaruh Model Pembelajaran Berbasis Masalah (Problem based Learning) dan Motivasi Belajar Terhadap Prestasi Belajar Fisika bagi Siswa Kelas VII SMP. Jurnal Teknologi Pembelajaran Indonesia, 1(2): $1-21$.

Nurqomariah, Gunawan, Sutrio. 2015. Pengaruh Model Problem Based Learning dengan Metode Eksperimen Terhadap Hasil Belajar IPA Fisika Siswa Kelas VII SMP Negeri 19 Mataram Tahun Pelajaran 2014/2015. Jurnal Pendidikan Fisika dan Teknologi, 1(3): 173178.

Paramata, D.D, Abdjul, T., Kansil, I.B. 2021. Implementation of The CLIS Model to Improve Student Learning Outcomes In Material Temperature and Changes. Turkish Journal of Computer and Mathematics Education, 12(1): 151 - 157.

Pohan, A.M., Asmin, Menanti, A. 2020. The Effect of Problem Based Learning and Learning Motivation of Mathematical Problem Solving Skills of Class 5 Students at SDN 0407 Mondang. Budapest International Based Learning (PBL) terhadap Prestasi Belajar Fisika Siswa dengan Menggunakan Tes Open Ended. Jurnal Pendidikan IPA IndonesiaJPII, 3(1): 8 - 11 .

Ismail, A. 2015. Penerapan Model Pembelajaran Children Learning In Science (CLIS) Berbantuan Multimedia Untuk Meningkatkan Penguasaan Konsep Fisika Siswa SMA. Research and Critics in Linguistics and Education (BirLE) Journal, 3(1): 531 - 539.

Putra, A.G.P., Bektiarso, S., Handayani, R.D. 2016. Pengaruh Model Problem Based Learning (PBL) terhadap Hasil Belajar dan Keterampilan Proses Sains dalam
Pembelajaran Fisika di SMA (Kelas X SMA Negeri 3 Jember). Jurnal Pembelajaran Fisika, 5(2): 129 - 134.

Rambega, U.L. 2016. Hubungan Antara Kemampuan Penalaran Formal dan Motivasi Belajar Fisika Terhadap Hasil Belajar Fisika Siswa SMPN 19 Bulukumba Kabupaten Bulukumba. Jurnal Pendidikan Fisika Universitas Muhammadiyah Makassar, 4(3): $276-290$

Septian, A., Komala, E. 2019. Kemampuan Koneksi Matematik dan Motivasi Belajar Siswa dengan Mengunakan Model Problem-Based Learning (PBL) Berbantuan Geogebra di SMP. Jurnal PRISMA Universitas Suryakancana, 8(1): 1 -13.

Siregar, S. (2014). Statistik Parametrik untuk Penelitian Kuantitatif Edisi 2. Jakarta: Bumi Aksara.

Supiandi, M.I., Julung, H. 2016. Pengaruh Model Problem Based Learning (PBL) terhadap Kemampuan Memecahkan Masalah dan Hasil Belajar Kognitif Siswa Biologi SMA. Jurnal Pendidikan Sains, 4(2): 60 - 64.

Suprihatin, S. 2015. Upaya Guru Dalam Meningkatkan Motivasi Siswa. Jurnal Promosi: Jurnal Pendidikan Ekonomi UM Metro, 3(1): $73-82$.

Tanti, Jamaluddin, Syefrinando, B. 2018. Pengaruh Pembelajaran Berbasis Masalah Terhadap Beliefs Siswa Tentang Fisika dan Pembelajaran Fisika. Jurnal Pendidikan Fisika Al-Biruni, 6(1): 23 - 36, doi: 10.24042/jpifalbiruni.v6i1.603.

Tomas, Prasetyo, T. 2020. Pengaruh Penggunaan Model Problem Based Learning (PBL) terhadap Motvasi Belajar Matematika pada Siswa Kelas 4 SD. Jurnal Pendidikan dan Pengajaran Guru Sekolah Dasar (JPPGuseda), 3(1): 13-18.

Widyoko, E.P. 2011. Evaluasi Program Pembelajaran. Yogyakarta: Pustaka Pelajar.

Yoannita, B., Budi, E., Rustana, C.E. 2016. Pengaruh Self Efficacy terhadap Hasil Belajar Fisika Melalui Penggunaan Model Problem Based Learning. Seminar Nasional Fisika 2016 (SNF2016), Universitas Negeri Jakarta, Jakarta, V, 9 - 14 